\title{
The Indicator of "Happiness" in the Resource-based Economy: an Extreme Approach
}

\author{
Lev S. Maergoiz ${ }^{\mathrm{a}}$ and Rem G. Khlebopros ${ }^{\mathrm{a}, \mathrm{b} *}$ \\ Siberian Federal University \\ a 79 Svobodny, Krasnoyarsk, 660041, Russia \\ ${ }^{b}$ Presidium of Krasnoyarsk Research Centre of SB RAS \\ 50 Akademgorodok, Krasnoyarsk, 660036, Russia
}

Received 03.04.2016, received in revised form 18.06.2016, accepted 30.06.2016

The article studies the problem of distributing the limited socio-economic resource using mathematical methods. The aspects of morals and justice can play a significant role in considering these problems. Such situation appears mostly when the consumers of the resource are groups of people in differentiated conditions. In this case, proportional distribution of the resource cannot be "fair" and the problem of searching for the distribution algorithm occurs, which would satisfy all groups, - the so called indicator of "happiness".

Keywords: fair distribution principles, limited socio-economic resource, mathematical algorithm.

DOI: 10.17516/1997-1370-2016-9-8-1739-1745.

Research area: economics.

Show people the results of injustice to make them love justice.

A. Smith

This problem is particularly acute in cases of emergency when the situation requires an "automatic" process of distribution of humanitarian aid between the areas affected by a natural disaster to a different extent. The first ones to need the distribution of the humanitarian aid will be the most affected part of the population. Since the inhabitants of the disaster areas need the humanitarian resources to a different extent, it is necessary to consider the moral aspect of this problem during the distribution, so that none of them is on the verge of life and death.

In the construction industry, there are tasks of collective investment control in the presence of investors ranking. To solve these tasks it is necessary to seek a compromise option of money deposits distribution. For example, investors have united into a team to participate in the construction of residential houses and are employed by the same firm. By the decision of the company management, investors are divided

(C) Siberian Federal University. All rights reserved

* Corresponding author E-mail address: olikru@yandex.ru 
into groups depending on their job experience. This means that the greater the experience the investors of the group have, the less is the cost of 1 sq. $m$ of housing for them.

On the other hand, in market conditions the company-developer faces a problem of obtaining the desired rate of return in real estate sales (e.g. residential building). This requires solving the problem of distribution of the cost of 1 sq. $\mathrm{m}$ of real estate parts depending on their prestige (e.g. different categories of flats of a residential house). Grading of the real estate parts on the basis of prestige can be obtained as a result of systemic studies of the offers of real estate agencies and other developers.

Thus, in one case, there are groups of investors with a variety of benefits, and in the other, a category of investors seeking for different parts of real estate in terms of prestige. Under these conditions, the problem of finding optimal investment strategies is quite urgent.

The task of equitable management of collective investment occurs also in case of uneven consumption of a resource, if each investor does not record the data on the scope of its consumption (for example, the cost of electricity for the lift use by the dwellers in a high-rise building). At the present time, payment for the lift depends on the size of the living area of a flat, regardless the floor on which it is located. At the same time, the residents of the first floor generally do not use the lift, while paying for such kind of services. Whereas the residents of the upper floors use this service very often. Thus, there is a question of "fair" distribution of payments for using the lift during a month, for example.

Similar problems of scarce resources distribution occur in other fields of public life. For example, at allocation of quotas for greenhouse gas emission between different countries. Attempts to solve this problem at the international level did not lead to positive results so far. In order to suspend the development of global warming processes, it is necessary to stabilize the state of the atmosphere at the current level. To this end, the international community is trying to negotiate on the issue of gradual reduction of emission by various countries to a different extent.

International legal framework for control and reduction of the negative anthropogenic impact leading to the emergence of the "greenhouse effect", today is presented by the United Nations Framework Convention on Climate Change of 1992 and Kyoto Protocol of 1997 associated herewith. One of the fundamental principles of the Convention is the principle of differentiated responsibility, which requires that the limitation of greenhouse gas emissions is equitable (emission reductions for developed countries). However, the implementation of this part causes most problems. The Kyoto Protocol contains specific, differentiated commitments for 39 contracting parties. At the Climate Change Conference in Copenhagen in December 2009, the project on reduction of global emissions by $50 \%$ by 2050 compared with 1990 , was approved with no obligations with respect to any specific country. Therefore, the problem of objectification of quotas for greenhouse gas emissions is quite urgent.

Therefore, there is a necessity to solve the problem of fair distribution of limited socio-economic resource between its different consumers (groups of people) in presence of their ranking.

To solve these problems of equitable distribution of limited socially important resources, a mathematical approach (optimization mathematical model) has been developed for its distribution between consumers (groups of people) in the presence of their ranking. "Distribution" of resources herewith took place in the presence of a numeric scale that reflects the scope of group's demands for a particular 
resource. For example, in the distribution of humanitarian aid in an emergency situation, the ranking of the affected areas was determined by an increase in the degree of the population needs in allocation of this resource, and the numerical scale contained the information on the number of people in each district (Gal'kova, 2008, 2012, 2015; Maergoiz, 2011).

Principles of remuneration in accordance with its quantity and quality are one of the most popular areas of study of production relations of people in economics and sociology. Fair wage distribution is an important condition for the absence of social tension at the workplace. Without pretending to review numerous references in this regard, let us note the closest article in relation to this work written by Iu.N. Gavrilets, which studied the ways to compromise the interests and equity in remuneration and considered the option of approaching justice "when there is no offense": when the satisfaction of each is not less than the satisfaction of any other. These principles of justice go back to Cicero:

\section{- There are two origins of justice:}

- do not harm and do good for the society.

Iu.N. Gavrilets and O.V. Staroverov offered structures of mathematical models for distribution of remuneration in a team using the function of its participants utility and considering their qualification, hard work and results of their work.

To encourage the staff members to show high results for a certain period a bonus pool is often formed. Let us consider the mathematical approach to its distribution, which is a modification to the method of optimal allocation of the limited socially significant resource among its consumers (groups of people), which are in differentiated conditions. The authors presented preliminary results of this approach in their previous works (Maergoiz, Khlebopros, 2014).
To solve the problem of allocation of the bonus pool among staff members, let us introduce two scales: the rating of the labour product categories based on their quality increase, the complexity of their manufacture (quality scale) and a numerical scale that characterizes the amount of work done to manufacture the products of labour of each category (quantity scale). For example, for a candy factory, which produces different kinds of cookies, candy, cakes, etc., the ranking of these products can be introduced based on the increasing complexity of technologies used for their manufacture. Unlike the previously discussed cases of resource distribution, if there is consumer ranking, one or another staff member may participate in manufacturing the products of labour of different categories.

To illustrate the bonus pool allocation algorithms, let us consider the problem of equitable distribution of the pool in a research team. The proposed algorithms are aimed at "objectification" of decisions taken in the framework of this problem of the team within the period being reviewed. Let us agree to determine the quality of each article by the category of the print edition, where it has been published. The first category incudes the collections (usually unreviewed) of scientific articles; the second category includes journals from the list of Higher Attestation Committee and peer-reviewed foreign journals without the impact factor; then there is the category of journals with a certain range of variation of the impact factor based on its growth. A number of research teams, universities among them, include professionals, which carry out research in various fields of knowledge (e.g. mathematics, physics, biology, chemistry, etc.). The adjustment range of the impact factor of scientific papers depends on the specialization of the studies. For example, the impact factor of mathematical journals is less than 4 , whereas the impact factor of the physical ones reaches $\sim 0$. Therefore, in such teams it is 
sensible to introduce the rating categories of scientific papers. Measuring the impact factor of a scientific paper by a relative scale, namely, determining the ratio of the journal impact factor, which published this work, and the maximum impact factor of scientific papers in the field of studies to which it relates.

Let us turn to the optimal mathematical model of fair allocation of the bonus pool in a research team.

Let us introduce the designations: $N>2$ stands for the category of the print editions; $C$ is the size of the bonus pool (in monetary equivalent); $S_{i}$ is the number of printed sheets of all scientific papers of the team published in the editions with the number $i, i=1,2, \ldots, N ; S=\sum_{i=1}^{N} S_{i} \quad$ is the total scientific papers of the team in printed sheets; $c=C / S$ is the average density of the bonus monetary resource per 1 printed sheet of the paper. From the mathematical point of view, the allocation of the bonus pool means dividing the variable sum

$$
C=\sum_{i=1}^{N} C_{i}
$$

where $C_{i}$ is the size of the pool's part intended for incentives of scientific papers published in editions with number $i$. Let us designate the density of the monetary resource per 1 printed sheet of products in these editions by $c_{i}=C_{i} / S_{i}$.

Further it would be more convenient to use dimensionless values $\lambda_{i}=c_{i} / c, i=1,2, \ldots, N$ (dimensionless densities of the resource for all categories of printed editions). Many of their allowed values are determined by the following ratio (Gal'kova, 2015):

$$
\sum_{i=1}^{N} \lambda_{i} s_{i}=1
$$

where $s_{i}=S_{i} / S$ is the percentage of printed products for the category with the number $i$, $i=1,2, \ldots, N$. At chosen fixed values of coefficients $\lambda_{1}, \lambda_{2}, \ldots, \lambda_{N}$ the sizes remuneration for the product of each category are defined by the following formula

$C_{i}<c \lambda_{i} S_{i}=\lambda_{i} s_{i} C, \quad i=1,2, \ldots, N$.

The principle of proportionality of the monetary resource allocation is natural.

Within any category, each team member receives a reward in proportion to the respective number of printed sheets of his contribution to the creation of a scientific paper published in the editions of this category (the proportionality principle within the category).

The given ranking means numeration of the categories of the scientific products' editions based on the increase of their "resource density" $0<c_{1}<c_{2}<\ldots<c_{N}$. Then

$0<\lambda_{1}<\lambda_{2}<\ldots<\lambda_{N}$

Provided that from (3) it follows, $\lambda_{1}<\lambda$, $\lambda_{N} \in\left(1,1 / S_{N}\right)$. Let us choose these parameters basing on the following principle.

Vector $\left(c_{2}-c_{1}, c_{3}-c_{2}, \ldots, c_{N}-c_{N-1}\right)$, the coordinates of which characterized the differences between the densities of the resource for the categories with the neighboring numbers, has the smallest length (optimality principle).

Let us associate the objective functional with the optimality principle

$$
\Phi(\lambda)=\sum_{i=1}^{N-1}\left(\lambda_{i+1}-\lambda_{i}\right)^{2}=c^{-2} \sum_{i=1}^{N-1}\left(c_{i+1}-c_{i}\right)^{2}
$$

which can be called " functional of justice". It is an analogue of the mean square of the same deviations - a popular functional in applied mathematics, because the minimum of each of the 
functionals at restrictions on the value considered below $\lambda_{i}=c_{i} / c, i=1,2, \ldots, N$ is achieved at the same values. Behind the proposed criterion of the bonus pool allocation, there is the principle of minimizing the above mentioned functionals depending on the differences of the densities of resources for the groups neighboring in the rating. This approach to the criterion selection is consistent with the principle "not to hurt anyone".

The minimum of the functional $\Phi$ (see (5)) on the condition (2) is equal 0 and is obtained at $\lambda_{i}=1, i=1,2, \ldots, N$. This means that the pool distribution among the team members is proportional to the number of printed sheets of their scientific products of any quality. This is unacceptable if there is a ranking between the categories. In order to avoid this, for optimization of the parameters of the mathematical model of the bonus pool distribution on the condition (5) (in the presence of the rating of "status value" of scientific papers), let us introduce "the management principle”, as an equation,

$$
\lambda_{1} / \lambda_{N}=c_{1} / c_{N}=\gamma
$$

where $\gamma$ is a fixed number from the interval $(0,1)$ with an evident economic meaning. In a specific research team the most demanded value of $\gamma$ can be chosen. The dimensionless densities of the resource for all categories of printed editions can be optimally chosen by finding the minimum point $\lambda_{i}=\lambda_{i}^{*}, i=1,2, \ldots, N$ of the functional $\Phi$ (see (5)) under the ratios (2), (4) and additional condition (6).

In the introduced designations (see (1), (2)), the "fair" amount $C_{i}$ of the resource intended as remuneration for the scientific papers of the category with number $i$, is determined by the equation

$C_{i}<c \lambda_{i} S_{i}=\lambda_{i} s_{i} C, \quad i=1,2, \ldots, N$.

where $\lambda_{i}=\lambda_{i}^{*}, i=1,2, \ldots, N$. The values of these parameters are found by means of standard optimization methods.

If in the designations of the formula (3)

$$
P_{j}=\sum_{i=j+1}^{N} s_{i}, Q_{j}=\sum_{i=1}^{j} s_{i}, \quad j=1, \ldots, N,
$$

then in (3) coefficients $\lambda_{1}^{*}, \lambda_{2}^{*}, \ldots, \lambda_{N}^{*}$ are determined in accordance with the formulas

$$
\lambda_{1}^{*}=\gamma \sum_{j=1}^{N-1} \frac{K_{j}}{\|K\|^{2}}, \quad \lambda_{k}^{*}=\lambda_{1}^{*}+(1-\gamma) \sum_{j=1}^{k-1} \frac{K_{j}}{\|K\|^{2}}, \quad k=2, \ldots, N,
$$

where

$$
K_{i}=P_{i}+\gamma Q_{j}, \quad j=1, \ldots, N-1 ; \quad\|K\|^{2}=\sum_{j=1}^{N-1} K_{j}^{2}
$$

The authors are sincerely grateful to Iu.V. Korotkova for providing very useful reference information for this work.

\section{References}

Gal'kova, E.A., Maergoiz, L.S. \& Khlebopros, R.S. (2008). Prilozhenie printsipa optimal'nosti $\mathrm{v}$ zadachakh upravleniia kollektivnym investirovaniem [Application of the optimality principle in the tasks of collective investment management], In Vestnik NGU. Sotsial'no-ekonomicheskie nauki [NSU Bulletin. Socio-economic Sciences]. 1 (8), 138-143.

Gal'kova, E.A., Maergoiz, L.S. \& Khlebopros, R.S. (2012). Matematicheskii algoritm "spravedlivogo" raspredeleniia gumanitarnogo resursa i smezhnye voprosy [Matematical algorithm of 
"fair" distribution of the humanitarian resource and related issues], In Sibirskii zhurnal industrial'noi matematiki [Siberian Journal of Industrial Mathematics], 4 (52) (15), 71-77.

Maergoiz, L.S., Sidorova, T.Iu. \& Khlebopros, R.G. (2011). Matematicheskii algoritm raspredeleniia vybrosov parnikovykh gazov [Mathematical algorithm of distributing green house gas emissions], In Sibirskii zhurnal industrial'noi matematiki [Siberian Journal of Industrial Mathematics], 2 (46) (14), 78-83.

Maergoiz L.S., Sidorova T.Iu. \& Khlebopros R.G. (2012). A Mathematical Algorithm of Distributing the Greenhouse Gas Emissions, In Journal of Applied and Industrial Mathematics, 2 (6), 210-215.

Gal'kova, E.A. \& Maergoiz, L.S. (2015). Matematicheskii podkhod k mnogoetapnomu raspredeleniiu sotsial'no znachimogo resursa pri nalichii reitinga potrebitelei [Mathematical approach to multi-stage distribution of socially significant resource in the presence of consumer ranking], In Vestnik NGU. Sotsial'no-ekonomicheskie nauki [NSU Bulletin. Socio-economic Sciences]. 1 (15), 1322.

Gal'kova, E.A. \& Maergoiz, L.S. (2015). Optimizatsionnaia matematicheskaia model' dvukhurovnevogo raspredeleniia ogranichennogo resursa mezhdu gruppami liudei [Optimization mathematical model of two-stage distribution of the limited resource between groups of people], In Ekonomika i matematicheskie metody [Economics and Mathematical Methods]. 3 (51), 109-116.

Gavrilets, Iu.N. (1992). Kompromiss interesov i spravedlivost' v oplate truda (model'nyi analiz) [Compromise of interests and justice in remuneration (model analysis)], In Ekonomika i matematicheskie metody [Economics and Mathematical Methods]. 4 (28), 16-28.

Staroverov, O.V. \& Kotel'nikova, S.N. (2001). Modelirovanie sotsial'no-ekonomicheskikh protsessov (uchebnoe posobie) [Modeling of socio-economic processes (tutorial)]. Moscow, Moskovskii gosudarstvennyi institut elektroniki i matematiki [Moscow State Institute of Electronics and Mathematics].

Maergoiz, L.S. (2014). Matematicheskii algoritm "spravedlivoi" oplaty truda nauchnogo kollektiva. [Mathematicalalgorithm of "fair" remunerationfora research team]. Matematicheskie metody i modeli v issledovanii sovremennykh problem ekonomiki i obshchestva. Vserossiiskaia molodezhnaia nauchno-prakticheskaia konferentsiia [Mathematical methods and models in the research of modern problems of economy and society. All-Russian Youth Scientific and Practical Conference]. Ufa, Publishing House of BashSU, 1, 31-34.

Maergoiz, L.S. \& Khlebopros, R.S. (2014). Matematicheskii algoritm "spravedlivoi” oplaty truda nauchnogo kollektiva [Mathematical algorithm of "fair" remuneration for a research team]. Preprint. Krasnoyarsk, Siberian Federal University, 12 p. 


\title{
Индикатор «счастья» в ресурсной экономике: \\ экстремальный подход
}

\author{
Л.С. Маергойз ${ }^{\mathrm{a}}$, Р.Г. Хлебопрос ${ }^{\mathrm{a}, \boldsymbol{\sigma}}$ \\ ${ }^{a}$ Сибирский федеральный университет \\ Россия, 660041, Красноярск, пр. Свободный, 79 \\ а,б Президиум Красноярского научного ичентра СО РАН \\ Россия, 660036, Красноярск, Академгородок, 50
}

Статья посвящена исследованию проблем распределения ограниченного ресурса социальноэкономического содержания математическими методами. При рассмотрении этих проблем существенную роль могут играть аспекты нравственности и справедливости. Такая ситуация возникает чаще всего, когда потребителями ресурса являются группь людей, находящиеся в дифференцированных условиях. В этом случае пропоричональное распределение ресурса не является «справедливым», и возникает проблема поиска алгоритма распределения, который удовлетворил бы все группы, - индикатора «счастья».

Ключевые слова: принцииь справедливого распределения, ограниченньй ресурс социиальноэкономического содержания, математический алгоритм.

Научная специальность: 08.00.00 - экономические науки. 